\title{
Analisis determinasi tingkat kemiskinan di kabupaten/kota Provinsi Jambi
}

\author{
*Rekha Alfionika; Yulmardi; Hardiani \\ Prodi Ekonomi Pembangunan Fak.Ekonomi dan Binsis Universitas Jambi \\ *E-mail korespondensi : rekhaalfionika002@gmail.com
}

\begin{abstract}
This study aims to: 1) To analyze economic growth, unemployment rates, education levels, labor force participation rates (TPAK) and poverty rates in Jambi Province districts / cities in 2013-2018. 2) To analyze the effect of economic growth, unemployment rate, education level and labor force participation rate (TPAK) on poverty levels in Jambi Province in 2013-2018. Based on the results of panel data regression, it can be concluded that economic growth, unemployment rate, education level and TPAK together have a significant effect on poverty levels in districts / cities in Jambi Province. Partially, the variable of economic growth and the level of education have a significant and negative effect on the level of poverty, while the variable unemployment rate and the level of labor force participation do not significantly influence the level of poverty in the districts / cities in Jambi Province.
\end{abstract}

Keywords: Poverty rate, Economic growth, Unemployment rate, Education level and labor force participation rate

\begin{abstract}
Abstrak
Penelitian ini bertujuan: 1) Untuk menganalisis pertumbuhan ekonomi, tingkat pengangguran, tingkat pendidikan, tingkat partisipasi angkatan kerja (TPAK) dan tingkat kemiskinan di Kabupaten/Kota Provinsi Jambi tahun 2013-2018. 2) Untuk menganalisis pengaruh pertumbuhan ekonomi, tingkat pengangguran, tingkat pendidikan dan tingkat partisipasi angkatan kerja (TPAK) terhadap tingkat kemiskinan di Provinsi Jambi tahun 2013-2018. Berdasarkan hasil regresi data panel dapat disimpulkan bahwa pertumbuhan ekonomi, tingkat pengangguran, tingkat pendidikan dan TPAK secara bersama-sama berpengaruh signifikan terhadap tingkat kemiskinan pada Kabupaten/Kota di Provinsi Jambi. Secara parsial, variabel pertumbuhan ekonomi dan tingkat pendidikan berpengaruh signifikan dan negatif terhadap tingkat kemiskinan, sementara variabel tingkat pengangguran dan tingkat partisipasi angkatan kerja tidak berpengaruh signifikan terhadap tingkat kemiskinan pada kabupaten/kota di Provinsi Jambi.
\end{abstract}

Kata kunci: Tingkat kemiskinan, Pertumbuhan ekonomi, Tingkat pengangguran, Tingkat pendidikan dan tingkat partisipasi angkatan kerja

\section{PENDAHULUAN}

Kemiskinan menjadi fenomena sepanjang sejarah Indonesia. Kemiskinan telah menjadikan jutaan anak-anak Indonesia tidak bisa mengenyam pendidikan yang berkualitas dan kesulitan membiayai kesehatan. Selain itu, kemiskinan juga menyebabkan kurangnya tabungan dan tidak adanya investasi, kurangnya akses ke 
pelayanan publik, disertai kurangnya lapangan pekerjaan, kurangnya jaminan sosial dan terbatasnya perlindungan terhadap keluarga. Lebih jauh kemiskinan meningkatkan arus urbanisasi ke kota, dan lebih parah lagi kemiskinan menyebabkan jutaan penduduk tidak bisa memenuhi kebutuhan pangan, sandang dan papan (Bappenas).

Provinsi Jambi merupakan salah satu daerah dengan tingkat kemiskinan terbesar ke 7 di Indonesia. Tingkat kemiskinan di Provinsi Jambi pada tahun 2013 adalah 6,68 persen, kemudian pada tahun 2014 meningkat menjadi sebesar 10,67, dan pada tahun 2015 tingkat kemiskinan di Provinsi Jambi sebesar 12,11 persen, pada tahun 2016 tingkat kemiskinan di Provinsi Jambi sebesar 10,73 persen, ditahun 2017 tingkat kemiskinan di Provinsi Jambi kembali menurun menjadi 10,53 persen dan tahun 2018 menurun lagi menjadi sebesar 10,08 persen dengan rata-rata tingkat kemiskinan selama enam tahun terakhir sebesar 10,76 persen.

Berdasarkan data dari BPS Provinsi Jambi (2019) bahwa tingkat kemiskinan di Kabupaten/Kota Provinsi Jambi periode tahun 2013 sampai dengan tahun 2018 cenderung menurun, namun dapat dilihat tingkat kemiskinan tertinggi tercatat pada Kabupaten Tanjung Jabung Timur dan Tanjung Jabung Barat yaitu sebesar 12,99 persen dan 11,57 persen. Selain 2 kabupaten tersebut, seluruh wilayah Provinsi Jambi tingkat kemiskinannya masih tinggi. Tingginya tingkat kemiskinan di Provinsi Jambi diduga disebabkan oleh beberapa faktor yaitu pertumbuhan ekonomi, tingkat pengangguran, tingkat pendidikan dan tingkat partisipasi angkatan kerja (TPAK).

Berdasarkan data yang dihimpun dari BPS (2019) bahwa pertumbuhan ekonomi Kabupaten/Kota Provinsi Jambi cenderung berfluktuasi, rata-rata pertumbuhan ekonomi Kabupaten/Kota Provinsi Jambi selama tahun 2013 sampai 2018 sebesar 5,78 persen, begitu juga dengan tingkat pengangguran dan tingkat partisipasi angkatan kerja juga mengalami fluktuasi dengan rata-rata tingkat pengangguran Kabupaten/Kota Provinsi Jambi selama tahun 2013 sampai 2018 sebesar 4,16 persen dan rata-rata tingkat partisipasi angkatan kerja sebesar 66,91 persen. Berbeda dengan tingkat pendidikan cenderung mengalami peningkatan setiap tahunnya dengan rata-rata tingkat pendidikan Kabupaten/Kota Provinsi Jambi selama tahun 2013 sampai 2018 sebesar 7,92 tahun.

Fenomena yang terjadi adalah selama periode tahun 2013-2018, terdapat beberapa tahun ditemukan saat pertumbuhan ekonomi, tingkat pendidikan dan tingkat partisipasi angkatan kerja mengalami peningkatan sementara kemiskinan juga mengalami peningkatan, seharusnya jika pertumbuhan ekonomi, tingkat pendidikan dan tingkat partisipasi angkatan kerja mengalami peningkatan maka kemiskinan mengalami penurunan. Begitu juga dengan penurunan pengangguran seharusnya dapat menurunkan kemikinan malah sebaliknya kemiskinan mengalami peningkatan.

Berdasarkan hal tersebut maka peneliti tertarik untuk meneliti lebih lanjut dalam bentuk skripsi yang berjudul "Analisis Determinasi Tingkat Kemiskinan di Kabupaten/Kota Provinsi Jambi".

\section{METODE}

Dalam melakukan suatu penelitian diperlukan metode yang sesuai sehingga dapat membantu peneliti dalam mengungkapkan permasalahan yang akan dikaji kebenarannya. Penggunaan metode dalam penelitian disesuaikan dengan masalah dan tujuan penelitian. Metode penelitian mempunyai kedudukan yang sangat penting dalam pelaksanaan pengumpulan dan analisis data. Metode penelitian yang digunakan penulis dalam penelitian ini adalah metode kuantitatif yaitu data yang diukur berdasarkan skala numerik atau angka (Amir, dkk 2019). 


\section{Jenis dan Sumber Data Jenis Data}

Data yang digunakan dalam penelitian ini adalah data sekunder berupa data yang diterbitkan atau digunakan oleh organisasi yang bukan pengolahnya (Amir, dkk 2019) dan merupakan data deret waktu (time series data) selama kurun waktu tahun 2013-2018 dan data deret lintang (cross section data) yang meliputi 11 kabupaten/kota di Provinsi Jambi.

\section{Sumber Data}

Data yang digunakan dalam penelitian ini dikumpulkan dari publikasi dan informasi data serta laporan-laporan yang dilakukan oleh dinas dan instansi terkait. Untuk memperoleh landasan teori, studi sebelumnya dan kerangka pemikiran dilakukan studi kepustakaan berupa buku-buku literatur. Sumber data yang digunakan dalam penelitian ini berasal dari Badan Pusat Statistik Provinsi Jambi dan instansi lainnya yangterkait.

\section{Metode Analisis Data}

Metode analisis dalam penelitian ini adalah metode deskriptif dengan pendekatan kualitatif dan kuantitatif. Analisis kualitatif digunakan untuk menggambarkan dan menguraikan keadaan persoalan yang didukung oleh fakta, sifat-sifat serta hubungan antara fenomena yang dianalisis, sementara analisis kuantitatif digunakan untuk mengolah data menggunakan regresi data panel.

Alat analisis yang digunakan untuk melihat sejauh mana pengaruh variabel bebas pertumbuhan ekonomi, tingkat pengangguran, tingkat pendidikan dan partisipasi angkatan kerja (TPAK) terhadap variabel terikat tingkat kemiskinan Kabupaten/kota di Provinsi Jambi tahun 2013-2018. Adapun model regresi yang digunakan adalah sebagai berikut (Gujarati, 2012):

$$
Y i t=\alpha+\alpha 1 X 1 i t+\alpha 2 X 2 i t+\alpha 3 X 3 i t+\alpha 4 X 4 i t+e i t
$$

Selanjutnya diubah menjadi persamaan berikut :

$$
\text { TKit }=\alpha+\alpha 1 P E i t+\alpha 2 T P G i t+\alpha 3 T P i t+\alpha 4 T P A K i t+e i t
$$

Dimana:

$\begin{array}{ll}\mathrm{TK}_{\mathrm{it}} & =\text { Tingkat Kemiskinan } \\ \mathrm{PE}_{\mathrm{it}} & =\text { Pertumbuhan Ekonomi } \\ \mathrm{TPG}_{\mathrm{it}} & =\text { Tingkat Pengangguran } \\ \mathrm{TP} & =\text { Tingkat Pendidikan } \\ \mathrm{TPAK}_{\mathrm{it}} & =\text { Tingkat Partisipasi Angkatan Kerja (TPAK) } \\ \boldsymbol{\alpha} 1, \boldsymbol{\alpha} 2, \boldsymbol{\alpha} 3, \boldsymbol{\alpha} 4 & =\text { Koefisien masing-masing variabel } \\ \boldsymbol{\alpha} 0 & =\text { Konstanta } \\ \mathrm{e} & \end{array}$

\section{HASIL DAN PEMBAHASAN}

Menganalisis pertumbuhan ekonomi, tingkat pengangguran, tingkat pendidikan, tingkat partisipasi angkatan kerja (TPAK) dan tingkat kemiskinan

\section{Perkembangan Tingkat Kemiskinan}

Kemiskinan merupakan masalah sosial yang senantiasa hadir di tengah-tengah masyarakat, kemiskinan merupakan konsep dan fenomena yang berwayuh wajah, bermatra multidimensional. Berikut ini dapat dilihat perkembangan tingkat kemiskinan Kabupaten/Kota di Provinsi Jambi pada Tabel 1: 
Tabel 1. Perkembangan Tingkat Kemiskinan Kabupaten/Kota di Provinsi Jambi Tahun 2013-2018 (Persen)

\begin{tabular}{|c|c|c|c|c|c|c|c|}
\hline \multirow[b]{2}{*}{ Wilayah } & \multirow[b]{2}{*}{2013} & \multicolumn{4}{|c|}{ Tingkat Kemiskinan (\%) } & \multirow[b]{2}{*}{2018} & \multirow[t]{2}{*}{ Rata- Rata } \\
\hline & & 2014 & 2015 & 2016 & 2017 & & \\
\hline Kerinci & 7,71 & 7,43 & 8,16 & 7,48 & 7,45 & 7,07 & 7,55 \\
\hline Merangin & 8,09 & 9,37 & 9,80 & 9,95 & 9,43 & 8,88 & 9,25 \\
\hline Sarolangun & 9,46 & 10,17 & 10,29 & 9,33 & 8,87 & 8,73 & 9,48 \\
\hline Batanghari & 10,13 & 10,50 & 10,69 & 10,79 & 10,33 & 10,23 & 10,45 \\
\hline Muaro Jambi & 5,08 & 4,45 & 4,63 & 4,30 & 4,37 & 4,05 & 4,48 \\
\hline Tanjung Jabung Timur & 12,50 & 13,55 & 14,17 & 12,76 & 12,58 & 12,38 & 12,99 \\
\hline Tanjung Jabung Barat & 10,92 & 11,64 & 12,63 & 11,81 & 11,32 & 11,10 & 11,57 \\
\hline Tebo & 6,35 & 6,89 & 7,12 & 6,87 & 6,79 & 6,58 & 6,77 \\
\hline Bungo & 5,55 & 5,12 & 5,70 & 5,99 & 5,82 & 5,78 & 5,66 \\
\hline Kota Jambi & 9,80 & 8,94 & 9,67 & 8,87 & 8,84 & 8,49 & 9,10 \\
\hline Kota Sungai Penuh & 3,66 & 3,33 & 3,43 & 3,13 & 2,78 & 2,76 & 3,18 \\
\hline Provinsi Jambi & 8,11 & 8,31 & 8,75 & 8,30 & 8,05 & 7,82 & 8,23 \\
\hline
\end{tabular}

Sumber : BPS Provinsi Jambi, 2019

Dapat dilihat pada tabel 1. mengenai tingkat kemiskinan di Kabupaten/Kota di Provinsi Jambi selama tahun 2013 sampai tahun 2018 dimana setiap tahunnya tingkat kemiskinan cenderung mengalami fluktuasi. Rata-rata perkembangan tingkat kemiskinan di Provinsi Jambi sebesar 8,23 persen. Tingkat kemiskinan di Provinsi Jambi terjadi dikarenakan faktor lapangan kerja yang sempit dan pertumbuhan pengangguran meningkat. Untuk rata-rata tingkat kemiskinan terbesar terjadi pada Tanjung Jabung Timur dengan rata-rata tingkat kemiskinan sebesar 12,99 persen. Tingginya tingkat kemiskinan di Kabupaten Tanjung Jabung Timur disebabkan lambatnya pergerakan perekonomian dan ketimpangan kesejahteraan ekonomi masyarakat sehingga masyarakat Kabupaten Tanjung Jabung Timur yang tidak memiliki pekerjaan tetap dan tidak memiliki lahan perkebunan akan terjebak dalam kemiskinan.

Sedangkan rata-rata tingkat kemiskinan terendah terjadi di Kota Sungai Penuh yaitu sebesar 3,18 persen, rendahnya tingkat kemiskinan di Kota Sungai Penuh disebabkan jumlah penduduk yang paling kecil dibanding kabupaten/kota lainnya dan Kota Sungai Penuh merupakan daerah pemekaran dari Kabupaten Kerinci sehingga banyaknya penduduk miskin tetap berada di Kabupaten Kerinci dan Kota Sungai Penuh yang awalnya sebelum pisah dari Kabupaten Kerinci merupakan suatu wilayah pusat perkonomian Kabupaten Kerinci. Seharusnya pemerintah Kabupaten/Kota di Provinsi Jambi harus bisa mengurangi kemiskinan dengan program-program penanggulangan kemiskinan seperti subsidi bahan pangan, jaminan kesehatan, dan sekolah gratis untuk masyarakat miskin.

\section{Perkembangan Pertumbuhan Ekonomi}

Pertumbuhan Ekonomi adalah suatu proses dimana terjadi kenaikan produk nasional bruto riil suatu perekonomian riil atau pendapatan riil. Jadi suatu perekonomian dapat dikatakan tumbuh atau berkembang bila terjadi output riil. Pertumbuhan ekonomi juga didefinisikan sebagai peningkatan dalam kapasitas suatu bangsa dalam jangka panjang untuk memproduksi aneka barang dan jasa bagi masyarakat, kapasitas ini 
bertumpu pada kemajuan teknologi produksi (Gerardo, P, dkk, 1991). Pertumbuhan ekonomi dihitung dengan perkembangan PDRB atas dasar harga konstan tahun 2010 menurut lapangan usaha. Selanjutnya untuk kondisi pertumbuhan ekonomi Kabupaten/Kota di Provinsi Jambi dapat kita lihat pada tabel berikut ini :

Tabel 2. Perkembangan Pertumbuhan Ekonomi Kabupaten/Kota di Provinsi Jambi Tahun 2013-2018 (Persen)

\begin{tabular}{lccccccc}
\hline & & \multicolumn{9}{c}{ Tingkat Kemiskinan(\%) } & & \begin{tabular}{c} 
Rata- \\
\cline { 3 - 6 } \multicolumn{1}{c}{ Wilayah }
\end{tabular} & $\mathbf{2 0 1 3}$ & $\mathbf{2 0 1 4}$ & $\mathbf{2 0 1 5}$ & $\mathbf{2 0 1 6}$ & $\mathbf{2 0 1 7}$ & $\mathbf{2 0 1 8}$ & Rata \\
\hline Kerinci & 7,71 & 7,43 & 8,16 & 7,48 & 7,45 & 7,07 & 7,55 \\
Merangin & 8,09 & 9,37 & 9,80 & 9,95 & 9,43 & 8,88 & 9,25 \\
Sarolangun & 9,46 & 10,17 & 10,29 & 9,33 & 8,87 & 8,73 & 9,48 \\
Batanghari & 10,13 & 10,50 & 10,69 & 10,79 & 10,33 & 10,23 & 10,45 \\
Muaro Jambi & 5,08 & 4,45 & 4,63 & 4,30 & 4,37 & 4,05 & 4,48 \\
Tanjung Jabung Timur & 12,50 & 13,55 & 14,17 & 12,76 & 12,58 & 12,38 & 12,99 \\
Tanjung Jabung Barat & 10,92 & 11,64 & 12,63 & 11,81 & 11,32 & 11,10 & 11,57 \\
Tebo & 6,35 & 6,89 & 7,12 & 6,87 & 6,79 & 6,58 & 6,77 \\
Bungo & 5,55 & 5,12 & 5,70 & 5,99 & 5,82 & 5,78 & 5,66 \\
Kota Jambi & 9,80 & 8,94 & 9,67 & 8,87 & 8,84 & 8,49 & 9,10 \\
Kota Sungai Penuh & 3,66 & 3,33 & 3,43 & 3,13 & 2,78 & 2,76 & 3,18 \\
Provinsi Jambi & 8,11 & 8,31 & 8,75 & 8,30 & 8,05 & 7,82 & 8,23 \\
\hline
\end{tabular}

Sumber : BPS Provinsi Jambi, 2019

Berdasarkan tabel 2. dapat dilihat bahwa pertumbuhan ekonomi Kabupaten/Kota di Provinsi Jambi selama periode tahun 2013 sampai tahun 2018 mengalami pertumbuhan yang berfluktuatif. Rata-rata pertumbuhan ekonomi di Provinsi Jambi hanya 5,78 persen. Rendahnya pertumbuhan ekonomi di Provinsi Jambi dikarenakan ketidakmerataan dan ketimpangan pembangunan ekonomi di dalam wilayah Provinsi Jambi, salah satunya pertumbuhan ekonomi Kabupaten Tanjung Jabung Timur dan Kabupaten Tanjung Jabung Barat yang lebih rendah dibandingkan daerah lainnya di Provinsi Jambi. Pertumbuhan ekonomi tertinggi tercatat pada Kota Sungai Penuh dengan rata-rata pertumbuhan ekonominya sebesar 6,96 persen setiap tahunnya, tingginya pertumbuhan ekonomi di Kota Sungai Penuh dikarenakan sektor pertanian merupakan sektor yang mendominasi dan berperan dalam roda perekonomian di Kota Sungai Penuh, pertumbuhan ekonomi yang paling tertinggi tercatat pada tahun 2013 yaitu sebesar 8,45 persen. Sedangkan pertumbuhan ekonomi terendah tercatat pada Kabupaten Tanjung Jabung Timur yaitu hanya sebesar 3,61 persen. Rendahnya pertumbuhan ekonomi di Kabupaten Tanjung Jabung Timur dikarenakan potensi sumber daya alam diwilayah ini tidak bisa diandalkan sebab wilayah di Kabupaten Tanjung Jabung Timur masih termasuk wilayah gambut sehingga tidak mendukung produksi di sektor pertanian dan perkebunan, begitu juga dengan sektor sekunder yang mana perusahaan tidak tertarik untuk melakukan investasi di wilayah ini.

\section{Perkembangan Tingkat Pengangguran}

Pengangguran adalah suatu keadaan di mana seseorang yang tergolong dalam angkatan kerja ingin mendapatkan pekerjaan tetapi belum dapat memperolehnya. 
Seseorang yang tidak bekerja, tetapi tidak secara aktif mencari pekerjaan tidak tergolong sebagai penganggur. Pengangguran dapat terjadi disebabkan oleh tidak seimbangan pada pasar tenaga kerja. Hal ini menunjukkan jumlah tenaga kerja yang ditawarkan melebihi jumlah tenaga kerja yang diminta. Semakin tinggi tingkat pengangguran maka semakin tinggi angka kemiskinan, karena pengangguran merupakan faktor penyebab kemiskinan. Adapun besaran tingkat pengangguran Kabupaten/Kota di Provinsi Jambi periode tahun 2013 - 2018 dapat dilihat pada tabel berikut ini.

Tabel 3. Perkembangan Tingkat Pengangguran Kabupaten/Kota di Provinsi Jambi Tahun 2013-2018 (persen)

\begin{tabular}{lccccccc}
\hline \multirow{1}{*}{ Wilayah } & \multicolumn{9}{c}{ Pertumbuhan Ekonomi (Persen) } & Rata- \\
\cline { 2 - 7 } & $\mathbf{2 0 1 3}$ & $\mathbf{2 0 1 4}$ & $\mathbf{2 0 1 5}$ & $\mathbf{2 0 1 6}$ & $\mathbf{2 0 1 7}$ & $\mathbf{2 0 1 8}$ & Rata \\
\hline Kerinci & 6,16 & 9,06 & 6,45 & 6,7 & 6,03 & 5,36 & 6,63 \\
Merangin & 6,45 & 7,13 & 5,48 & 6,21 & 5,55 & 4,89 & 5,95 \\
Sarolangun & 7,61 & 5,2 & 3,09 & 4,26 & 4,69 & 5,12 & 5,00 \\
Batanghari & 6,48 & 7,56 & 4,36 & 4,55 & 4,82 & 5,09 & 5,48 \\
Muaro Jambi & 7,15 & 8,03 & 5,24 & 5,43 & 5,06 & 4,69 & 5,93 \\
Tanjung Jabung Timur & 4,57 & 5,81 & 1,87 & 2,7 & 3,13 & 3,56 & 3,61 \\
Tanjung Jabung Barat & 5,73 & 5,85 & 3,98 & 3,14 & 4,25 & 5,36 & 4,72 \\
Tebo & 7,63 & 8,83 & 5,28 & 5,38 & 5,6 & 5,82 & 6,42 \\
Bungo & 9,02 & 6,74 & 5,13 & 5,2 & 5,67 & 6,14 & 6,32 \\
Kota Jambi & 8,5 & 8,17 & 5,56 & 6,81 & 4,68 & 5,55 & 6,55 \\
Kota Sungai Penuh & 8,45 & 7,54 & 7,06 & 6,51 & 6,24 & 5,97 & 6,96 \\
Provinsi Jambi & 7,07 & 7,27 & 4,86 & 5,17 & 5,07 & 5,23 & 5,78 \\
\hline
\end{tabular}

Sumber : BPS Provinsi Jambi, 2019

Dapat dilihat pada tabel 3. mengenai tingkat pengangguran di Kabupaten/Kota di Provinsi Jambi selama tahun 2013 sampai tahun 2018 dimana setiap tahunnya tingkat pengangguran cenderung mengalami fluktuasi. Rata-rata tingkat pengangguran di Provinsi Jambi selama tahun 2013 sampai tahun 2018 sebesar 4,17 persen. Pengangguran di Provinsi Jambi meningkat dikarenakan tenaga kerja terdidik yang terus mengalami peningkatan setiap tahunnya namun tidak diiringi dengan lapangan kerja yang tersedia. Untuk rata-rata tingkat pengangguran tertinggi terjadi pada Kota Jambi dengan rata-rata tingkat pengangguran sebesar 6,91 persen. Tingginya tingkat pengangguran di Kota Jambi karena banyaknya penduduk dari daerah lain untuk mencari kerja di Kota Jambi sementara peluang kerja tidak mampu menyanggupi sehingga menumpuk jumlah pengangguran di Kota Jambi.

Sedangkan rata-rata tingkat pengangguran terendah terjadi di Kabupaten Tanjung Jabung Timur yaitu sebesar 2,11 persen, rendahnya tingkat pengangguran di Kabupaten Tanjung Jabung Timur disebabkan banyaknya penduduk bekerja di perusahaan asing seperti Petrocina dan perusahaan lainnya yang berada dalam wilayah Kabupaten Tanjung Jabung Timur. Seharusnya pemerintah Kabupaten/Kota di Provinsi Jambi harus bisa mengurangi pengangguran dengan program-program pengentasan pengangguran seperti membuka kesempatan kerja yang besar bagi tenaga kerja.

\section{Perkembangan Tingkat Pendidikan}

Analisis capaian pendidikan dapat dilihat dari Rata-rata lama Sekolah - RLS (Mean Years of Schooling - MYS). Rata-rata lama sekolah didefenisikan sebagai jumlah 
tahun yang digunakan penduduk dalam menjalani pendidikan formal. Cakupan penduduk yang dihitung dalam perhitungan rata-rata lama sekolah adalah pendidikan usia 15 tahun keatas. Semakin tinggi tingkat pendidikan cenderung semakin besar peluang masyarakat atau penduduk dalam mencari pekerjaan dan menciptakan lapangan pekerjaan, karena semakin tinggi ilmu dan pengalaman selama menempuh pendidikan. Adapun besaran tingkat pendidikan kabupaten/kota di Provinsi Jambi periode tahun 2013 - 2018 dapat dilihat pada tabel berikut ini.

Tabel 4. Perkembangan Tingkat Pendidikan Provinsi Jambi Periode 2013-2018 (Tahun)

\begin{tabular}{|c|c|c|c|c|c|c|c|}
\hline \multirow{2}{*}{ Wilayah } & \multicolumn{6}{|c|}{ Tingkat Pendidikan (Tahun) } & \multirow{2}{*}{ Rata-Rata } \\
\hline & 2013 & 2014 & 2015 & 2016 & 2017 & 2018 & \\
\hline Kerinci & 7,71 & 7,77 & 7,78 & 8,06 & 8,19 & 8,28 & 7,97 \\
\hline Merangin & 7 & 7,04 & 7,08 & 7,44 & 7,62 & 7,73 & 7,32 \\
\hline Sarolangun & 7,12 & 7,23 & 7,24 & 7,34 & 7,47 & 7,52 & 7,32 \\
\hline Batanghari & 7,41 & 7,43 & 7,44 & 7,69 & 7,77 & 7,84 & 7,60 \\
\hline Muaro Jambi & 7,56 & 7,68 & 8,01 & 8,02 & 8,08 & 8,28 & 7,94 \\
\hline Tanjung Jabung Timur & 5,9 & 5,93 & 6,26 & 6,32 & 6,33 & 6,52 & 6,21 \\
\hline Tanjung Jabung Barat & 7,24 & 7,28 & 7,37 & 7,43 & 7,44 & 7,52 & 7,38 \\
\hline Tebo & 7,27 & 7,48 & 7,53 & 7,54 & 7,55 & 7,66 & 7,51 \\
\hline Bungo & 7,85 & 7,86 & 7,87 & 7,99 & 8,08 & 8,11 & 7,96 \\
\hline Kota Jambi & 10,55 & 10,62 & 10,63 & 10,65 & 10,66 & 10,7 & 10,64 \\
\hline Kota Sungai Penuh & 8,97 & 9,05 & 9,17 & 9,33 & 9,55 & 9,65 & 9,29 \\
\hline Provinsi Jambi & 7,69 & 7,76 & 7,85 & 7,98 & 8,07 & 8,16 & 7,92 \\
\hline
\end{tabular}

Sumber : BPS Provinsi Jambi, 2019

Berdasarkan tabel 4. dapat dilihat bahwa tingkat pendidikan yang diukur dengan rata-rata lama sekolah pada setiap Kabupaten/Kota di Provinsi Jambi selama tahun 2013-2018 mengalami perkembangan yang terus meningkat. Rata-rata tingkat pendidikan di Provinsi Jambi hanya 7,92 tahun. Rendahnya tingkat pendidikan di Provinsi Jambi dikarenakan peningkatan kualitas pendidikan yang tidak tersebar secara merata. Rata-rata tingkat pendidikan tertinggi tercatat di Kota Jambi dengan tingkat pendidikan sebesar 10,64, artinya penduduk di Kota Jambi rata-rata pendidikannya adalah 10,64 tahun atau mencapai pendidikan kelas 2 SMA. Sedangkan Rata-rata tingkat pendidikan terendah tercatat di Kabupaten Tanjung Jabung Timur dengan tingkat pendidikan sebesar 6,21, artinya penduduk di Kabupaten Tanjung Jabung Timur rata-rata pendidikannya adalah 6,21 tahun atau mencapai pendidikan kelas 6 SD.

Selanjutnya rata-rata perkembangan tingkat pendidikan tertinggi tercatat di Kabupaten Merangin dengan rata-rata perkembangan sebesar 2,61 persen. Hal ini menunjukkan bahwa perbaikan tingkat pendidikan di Kabupaten Merangin lebih cepat dibandingkan Kabupaten/Kota lainnya di Provinsi Jambi. Sedangkan rata-rata perkembangan tingkat pendidikan terendah tercatat di Kota Jambi dengan rata-rata perkembangan hanya sebesar 0,26 persen. Ini menunjukkan bahwa perbaikan tingkat pendidikan di Kota Jambi masih belum optimal dibandingkan Kabupaten/Kota lainnya di Provinsi Jambi. 


\section{Perkembangan Tingkat Partispasi Angkatan Kerja}

Tingkat partisipasi angkatan kerja (TPAK) menunjukkan semakin banyak masyarakat yang produktif, maka akan menghasilkan output yang tinggi pula yang mempengaruhi pertumbuhan ekonomi. Adapun besaran tingkat pendidikan Kabupaten/Kota di Provinsi Jambi periode tahun 2013 - 2018 dapat dilihat pada Tabel berikut ini.

Tabel 5. Perkembangan tingkat partisipasi angkatan kerja Provinsi Jambi Periode 20132018 (Tahun)

\begin{tabular}{|c|c|c|c|c|c|c|c|}
\hline \multirow{2}{*}{ Wilayah } & \multicolumn{6}{|c|}{ Tingkat Partisipasi Angkatan Kerja (Persen) } & \multirow{2}{*}{ Rata-Rata } \\
\hline & 2013 & 2014 & 2015 & 2016 & 2017 & 2018 & \\
\hline Kerinci & 69,32 & 67,6 & 71,39 & 70,26 & 69,46 & 70,49 & 69,75 \\
\hline Merangin & 60,9 & 63,6 & 64,63 & 67,44 & 69,82 & 71,78 & 66,36 \\
\hline Sarolangun & 66,05 & 66,76 & 70,5 & 70,31 & 70,08 & 72,22 & 69,32 \\
\hline Batanghari & 65,25 & 64,22 & 63,82 & 64,18 & 64,39 & 63,84 & 64,28 \\
\hline Muaro Jambi & 58,09 & 61,19 & 61,13 & 61,98 & 62,3 & 63,7 & 61,40 \\
\hline Tanjung Jabung Timur & 64,75 & 70,3 & 68,18 & 72,63 & 75,97 & 77,8 & 71,61 \\
\hline Tanjung Jabung Barat & 59,43 & 66,83 & 67,12 & 69,14 & 70,24 & 73,73 & 67,75 \\
\hline Tebo & 63,23 & 72,75 & 71,97 & 72,79 & 70,61 & 74,71 & 71,01 \\
\hline Bungo & 64,89 & 66,09 & 63,8 & 64,11 & 65,89 & 64,96 & 64,96 \\
\hline Kota Jambi & 60,8 & 62,39 & 64,04 & 65,23 & 64,06 & 66,11 & 63,77 \\
\hline Kota Sungai Penuh & 61,37 & 65,41 & 67,03 & 66,49 & 66,05 & 68,4 & 65,79 \\
\hline Provinsi Jambi & 63,10 & 66,10 & 66,69 & 67,69 & 68,08 & 69,79 & 66,91 \\
\hline
\end{tabular}

Sumber : BPS Provinsi Jambi, 2019

Berdasarkan Tabel 5. dapat dilihat bahwa TPAK pada setiap Kabupaten/Kota di Provinsi Jambi selama tahun 2013-2018 mengalami perkembangan berfluktuasi. Ratarata TPAK Provinsi Jambi sebesar 66,91 persen. Besarnya TPAK Provinsi Jambi dikarenakan pertumbuhan jumlah penduduk usia kerja yang terus meningkat setiap tahunnya. Rata-rata TPAK tertinggi tercatat di Kabupaten Tanjung Jabung Timur dengan TPAK sebesar 71,61 persen, artinya penduduk yang produktif dalam mencari pekerjaan sebesar 71,61 persen. Sedangkan rata-rata TPAK terendah tercatat di Kabupaten Muaro Jambi dengan TPAK sebesar 61,40 persen, artinya penduduk yang produktif dalam mencari pekerjaan hanya sebesar 61,40 persen.

Pengaruh Pertumbuhan Ekonomi, Tingkat Pengangguran, Tingkat Pendidikan dan Tingkat Partisipasi Angkatan Kerja (TPAK) Terhadap Tingkat Kemiskinan

Bagian ini akan menjelaskan bagaimana pertumbuhan ekonomi, upah minimum, tingkat pendidikan dan pengangguran terhadap kemiskinan di Provinsi Jambi yang menggunakan perhitungan regresi data panel yaitu menggunakan data time series adalah data tahunan t yaitu tahun 2013-2018 dan cross section adalah Objek data yaitu meliputi 11 Kabupaten/Kota yang ada di Provinsi Jambi. Variabel bebas yang digunakan yaitu pertumbuhan ekonomi, tingkat pengangguran, tingkat pendidikan dan partispasi angkatan kerja dan variabel terikatnya adalah tingkat kemiskinan. 


\section{Hasil pengujian estimasi model FEM}

Hasil estimasi persamaan data panel tentang pengaruh pertumbuhan ekonomi, tingkat pengangguran, tingkat pendidikan dan partisipasi angkatan kerja terhadap tingkat kemiskinan adalah sebagai berikut:

Tabel 6. Hasil estimasi fixed effects model (FEM)

Dependent Variable: TK? Method: Pooled Least Squares Date: 11/10/19 Time: 16:38 Sample: 20132018 Included observations: 6

Cross-sections included: 11

Total pool (balanced) observations: 66

\begin{tabular}{|c|c|c|c|c|}
\hline Variable & Coefficient & Std. Error & t-Statistic & Prob. \\
\hline $\mathrm{C}$ & 17.59853 & 3.269122 & 5.383260 & 0.0000 \\
\hline PE? & -0.111586 & 0.059417 & -1.878016 & 0.0661 \\
\hline TPG? & -0.023040 & 0.047231 & -0.487815 & 0.6278 \\
\hline TP? & -1.193425 & 0.475657 & -2.509005 & 0.0153 \\
\hline TPAK? & 0.012231 & 0.028395 & 0.430746 & 0.6685 \\
\hline Fixed Effects (Cross) & & & & \\
\hline KERINCI-C & -0.561145 & & & \\
\hline MERANGIN-C & 0.344244 & & & \\
\hline SAROLANGUN--C & 0.399891 & & & \\
\hline BATANGHARI--C & 1.829246 & & & \\
\hline MUAROJAMBI--C & -3.621443 & & & \\
\hline _TANJABTIM-C & 2.377832 & & & \\
\hline _TANJABBAR--C & 2.541984 & & & \\
\hline -TEBO_C & -1.975750 & & & \\
\hline BUNGO-C & -2.429311 & & & \\
\hline KOTAJAMBI-C & 4.304643 & & & \\
\hline SUNGAIPENUH--C & -3.210192 & & & \\
\hline \multicolumn{5}{|c|}{ Effects Specification } \\
\hline \multicolumn{5}{|c|}{ Cross-section fixed (dummy variables) } \\
\hline R-squared & \multicolumn{2}{|c|}{0.979592 Mean dependent var } & \multicolumn{2}{|c|}{8.224848} \\
\hline Adjusted R-squared & \multicolumn{2}{|c|}{0.973990 S.D. dependent var } & \multicolumn{2}{|c|}{2.930615} \\
\hline S.E. of regression & \multicolumn{2}{|c|}{0.472643 Akaike inf } & \multicolumn{2}{|c|}{1.535763} \\
\hline Sum squared resid & \multicolumn{2}{|l|}{11.39295} & \multicolumn{2}{|c|}{2.033411} \\
\hline Log likelihood & \multicolumn{2}{|c|}{-35.68017 Hannan-Quinn criter. } & \multicolumn{2}{|c|}{1.732407} \\
\hline F-statistic & \multicolumn{2}{|c|}{174.8565 Durbin-Watson stat } & \multicolumn{2}{|c|}{1.381388} \\
\hline Prob(F-statistic) & 0.000000 & & & \\
\hline
\end{tabular}

Sumber: Data Diolah, Eviews 9 (2019)

\section{Estimasi Model FEM}

\section{Estimasi Koefisien Variabel Model FEM}

Berdasarkan hasil estimasi tingkat pendidikan pada tabel 7. tersebut dapat diketahui penjelasan masing-masing variabel dalam penelitian, yaitu pertumbuhan ekonomi, tingkat pengangguran, tingkat pendidikan dan tingkat partisapasi angkatan kerja terhadap tingkat kemiskinan dapat dijelaskan persamaan model sebagai berikut:

TK $_{i t}=17,598-0,1116 P E_{i t}-0,0230 T P G_{i t}-1,1934 T P_{i t}+0,0122 T P A K_{i t}+e_{i t}$ Prob $=(0,0661)(0,6278)(0,0153)(0,6685)$

Berdasarkan Persamaan Model diatas dapat dijelaskan hasil estimasi terhadap fixed effect adalah jika terjadi perubahan antara pertumbuhan ekonomi, tingkat pengangguran, tingkat pendidikan, dan tingkat partisipasi angkatan kerja baik antar wilayah maupun antar waktu, maka nilai konstanta sebesar 17,598. Hal ini berarti apabila pertumbuhan ekonomi, tingkat pengangguran, tingkat pendidikan, dan tingkat partisipasi angkatan kerja tetap maka tingkat kemiskinan Kabupaten/Kota di Provinsi Jambi sebesar 17,598 persen. 
Nilai koefisien pertumbuhan ekonomi sebesar -0,1116. Hal ini diartikan jika pertumbuhan ekonomi meningkat satu persen maka tingkat kemiskinan Kabupaten/Kota di Provinsi Jambi menurun sebesar -0,1116 persen. Nilai koefisien tingkat pengangguran sebesar -0,0230. Hal ini diartikan jika tingkat pengangguran meningkat satu persen maka tingkat kemiskinan Kabupaten/Kota di Provinsi Jambi menurun sebesar -0,0230 persen. Nilai koefisien tingkat pendidikan sebesar -1,1934. Hal ini diartikan jika tingkat pendidikan meningkat satu tahun maka tingkat kemiskinan Kabupaten/Kota di Provinsi Jambi menurun sebesar -1,1934. Nilai koefisien tingkat partisipasi angkatan kerja sebesar 0,0122. Hal ini diartikan jika tingkat partisipasi angkatan kerja meningkat satu persen maka tingkat kemiskinan Kabupaten/Kota di Provinsi Jambi meningkat sebesar 0,0122 persen

\section{Uji hipotesis Uji F statistik}

Dapat dilihat tingkat pendidikan pada tabel 6 diatas diketahui juga bahwa nilai Prob (f Statistik) 0,0000<0,1, maka berarti Ho ditolak dan menerima Ha, yang artinya uji secara bersama sama menunjukkan pertumbuhan ekonomi, tingkat pengangguran, tingkat pendidikan, dan tingkat partisipasi angkatan kerja secara simultan berpengaruh signifikan terhadap tingkat kemiskinan kabupaten/kota di Provinsi Jambi.

\section{Uji $\mathbf{R}^{2}$}

Dapat dilihat pada Tabel 6 bahwa nilai R-Squared adalah sebesar 0,9795 artinya bahwa variabel tingkat kemiskinan dapat dijelaskan oleh variabel bebas pada tingkat korelasinya sebesar 97,95 persen.

\section{Uji t statistik}

Untuk menguji signifikasi pengaruh pertumbuhan ekonomi, tingkat pengangguran, tingkat pendidikan, dan tingkat partisipasi angkatan kerja terhadap tingkat kemiskinan pada Kabupaten/Kota di Provinsi Jambi secara parsial maka digunakan uji t statistik. Uji $\mathrm{t}$ Statistik berguna untuk melihat besarnya pengaruh masing-masing variabel independen terhadap variabel dependen secara parsial. Tingkat kepercayaan 90 persen dengan uji dua arah dan dapat diterangkan hasil uji t statistik sebagai berikut: Jika dilihat dari Prob pertumbuhan ekonomi sebesar 0,0661 karena Prob $<0,1$ persen, maka $\mathrm{H}_{0}$ ditolak dan $\mathrm{H}_{\mathrm{a}}$ diterima. Ini menunjukkan bahwa pertumbuhan ekonomi berpengaruh signifikan terhadap tingkat kemiskinan pada Kabupaten/Kota di Provinsi Jambi. Jika dilihat dari Prob tingkat pengangguran sebesar 0,6278 karena Prob > 0,1 persen, maka $\mathrm{H}_{0}$ diterima dan $\mathrm{H}_{\mathrm{a}}$ ditolak. Ini menunjukkan bahwa tingkat pengangguran tidak berpengaruh terhadap tingkat kemiskinan pada Kabupaten/Kota di Provinsi Jambi. Jika dilihat dari Prob tingkat pendidikan sebesar 0,0153 karena Prob $<0,1$, maka $\mathrm{H}_{0}$ ditolak dan $\mathrm{H}_{\mathrm{a}}$ diterima. Ini menunjukkan bahwa tingkat pendidikan berpengaruh signifikan terhadap tingkat kemiskinan Kabupaten/Kota di Provinsi Jambi. Jika dilihat dari Prob tingkat partispasi angkatan kerja sebesar 0,6685 karena Prob $>0,1$ persen, maka $\mathrm{H}_{0}$ diterima dan $\mathrm{H}_{\mathrm{a}}$ ditolak. Ini menunjukkan bahwa tingkat partispasi angkatan kerja tidak berpengaruh signifikan terhadap tingkat kemiskinan pada Kabupaten/Kota di Provinsi Jambi.

\section{Analisis Ekonomi}

Berdasarkan hasil regresi pada model FEM disebutkan nilai koefisien pertumbuhan ekonomi sebesar -0,1116. Hal ini diartikan jika pertumbuhan ekonomi meningkat satu persen maka tingkat kemiskinan Kabupaten/Kota di Provinsi Jambi 
menurun sebesar -0,1116 persen. Pertumbuhan ekonomi berpengaruh signifikan terhadap tingkat kemiskinan pada Kabupaten/Kota di Provinsi Jambi. Hasil ini sependapat dengan penelitian yang dilakukan Wongdesmiwati (2009), menemukan bahwa terdapat hubungan yang negatif antara pertumbuhan ekonomi dan tingkat kemiskinan. Kenaikan pertumbuhan ekonomi akan menurunkan tingkat kemiskinan. Hubungan ini menunjukkan pentingnya mempercepat pertumbuhan ekonomi untuk menurunkan kemiskinan. Berpengaruhnya pertumbuhan ekonomi terhadap tingkat kemiskinan di Kabupaten/Kota Provinsi Jambi dikarenakan meningkatnya pertumbuhan ekonomi, memperluas kesempatan kerja termasuk dalam penyerapan tenaga kerja penduduk miskin.

Berdasarkan hasil regresi pada model FEM disebutkan nilai koefisien tingkat pendidikan sebesar -1,1934. Hal ini diartikan jika tingkat pendidikan meningkat satu tahun maka tingkat kemiskinan Kabupaten/Kota di Provinsi Jambi menurun sebesar $-1,1934$ persen. Tingkat pendidikan berpengaruh signifikan terhadap tingkat kemiskinan pada Kabupaten/Kota di Provinsi Jambi. Hasil ini sependapat dengan penelitian yang dilakukan oleh Todaro dan Smith (2006) menyatakan bahwa tingkat pendidikan berpengaruh negatif terhadap tingkat kemiskinan. Berpengaruhnya tingkat pendidikan terhadap tingkat kemiskinan disebabkan seseorang yang berpendidikan yang tinggi akan mempermudah seseorang tersebut dalam mendapatkan pekerjaan sehingga disaat seseorang tersebut telah mendapatkan penghasilan maka seseorang tersebut akan cukup memenuhi kebutuhan hidupnya dan terhindar dari kemiskinan.

\section{KESIMPULAN DAN SARAN Kesimpulan}

Kesimpulan yang dapat diambil dalam penelitian ini adalah sebagai berikut: Rata- rata perkembangan tingkat kemiskinan di Provinsi Jambi selama tahun 2013 sampai tahun 2018 sebesar 8,23 persen. Rata-rata pertumbuhan ekonomi di Provinsi Jambi 5,78 persen. Rata-rata tingkat pengangguran di Provinsi Jambi selama tahun 2013 sampai tahun 2018 sebesar 4,17 persen. Rata-rata tingkat pendidikan di Provinsi Jambi 7,92 persen. Rata-rata TPAK Provinsi Jambi sebesar 66,91 persen. Pertumbuhan ekonomi, tingkat pengangguran, tingkat pendidikan dan TPAK secara bersama-sama berpengaruh signifikan terhadap tingkat kemiskinan pada Kabupaten/Kota di Provinsi Jambi. Secara parsial, variabel pertumbuhan ekonomi dan tingkat pendidikan berpengaruh signifikan dan negatif terhadap tingkat kemiskinan, sementara variabel tingkat pengangguran dan tingkat partisipasi angkatan kerja tidak berpengaruh signifikan terhadap tingkat kemiskinan pada Kabupaten/Kota di Provinsi Jambi.

\section{Saran}

Saran yang dapat diambil dari penelitian ini adalah sebagai berikut: Tingkat kemiskinan pada Kabupaten/Kota di Provinsi Jambi selama tahun 2013-2018 harus dapat dikurangi setiap tahunnya, yaitu dengan membuat kebijakan-kebijakan pengurangan tingkat kemiskinan dengan dikaitkan dengan variabel pertumbuhan ekonomi dan tingkat pendidikan. Pemerintah harus dapat meningkatkan pertumbuhan ekonomi yang melibatkan penduduk miskin didalamnya dan Pemerintah harus meningkatkan tingkat pendidikan pada indikator rata-rata lama sekolah dengan cara meningkatkan anggaran pemerintah untuk beasiswa bagi siswa yang tidak mampu, menetapkan standar minimal sekolah minimal sekolah 12 tahun dan membuat peraturan tentang kewajiban kepada perusahaan-perusahaan besar agar memberikan bantuan berupa beasiswa hingga jenjang perkulihan bagi siswa yang tidak mampu. Untuk 
penelitian selanjutnya diharapkan agar dapat mengganti variabel bebas yang tidak berpengaruh dengan variabel bebas lainnya agar hasil penelitia lebih baik lagi.

\section{DAFTAR PUSTAKA}

Amir, Junaidi dan Yulmardi. (2019). Metodologi Penelitian Ekonomi dan Penerapannya. IPB Press: Bogor.

Bank Dunia. (2006). Era Baru dalam Pengentasan Kemiskinan di Indonesia diakses melalui http://sofian.staff.ugm.ac.id/artikel/Ikhtisar-Laporan-BD-ttg Kemiski nan-di-Indonesia. Diakes Tanggal 21 Oktober 2018, Pukul 20.00 WIB

BPS. (2019). Tingkat Kemiskinan, Pertumbuhan Ekonomi, Tingkat Pengangguran, RataRata Lama Sekolah dan Tingkat Partispasio Angkatan Kerja 2013-2018. Jambi dalam Angka 2018: Jambi.

Gujarati, Damodar. (2012). Dasar-Dasar Ekonometrika. Erlangga: Jakarta.

Halim. (2004). Manajemen Keuangan Daerah. Salemba Empat: Jakarta.

Lanjouw, P. (2005). Poverty Education and Health in Indonesia : Who Benefits From Public Spending. Word Bank Working Paper No. 2739; Washington DC http://papers.ssrn.com/sol3/papers.cfm?abstract_id=634451 Diakses tanggal 2 Maret 2014 , Pukul 20.00 WIB.

Mankiw, N. Gregory. (2006). Pengantar Ekonomi Makro. Ghalia Indonesia: Jakarta.

Nachrowi, Djalal Nachrowi, Hardius Usman. (2006). Pendekatan Populer dan Praktis Ekonometrika untuk Analisis Ekonomi dan Keuangan. Lembaga Universitas Indonesia: Jakarta.

Todaro, Michael P. dan Stephen C. Smith. (2006). Pembangunan Ekonomi (edisi kesembilan, jilid I). Erlangga: Jakarta.

Wongdesmiwati.(2009). Pertumbuhan Ekonomi dan Pengentasan Kemiskinan di Indonesia, diakses melalui http://wongdesmiwati.word press.com/2018/10/24/pertumbuhan-ekonomi-dan-pengentasan-kemiskinan-diindonesia-analisis-ekonometri. 